\title{
Perceptions of Teachers on the Ban of Corporal Punishment in Pre-Primary Institutions in Kenya
}

\author{
Beth Kirigo Mwai ${ }^{1}$, Isaac Njuguna Kimengi ${ }^{1,{ }^{*}}$ \& Emmy Jerono Kipsoi ${ }^{1}$ \\ ${ }^{1}$ Department of Educational Foundations, Moi University, P.O. Box 3900-30100, Eldoret, Kenya \\ *Corresponding author: Department of Educational Foundations, Moi University, P.O. Box 3900-30100, Eldoret, \\ Kenya. E-mail: kin7559@yahoo.com
}

Received: November 1, 2014

Accepted: November 26, $2014 \quad$ Online Published: December 12, 2014

doi:10.5430/wje.v4n6p90

URL: http://dx.doi.org/10.5430/wje.v4n6p90

\begin{abstract}
The purpose of the study was to investigate perceptions of teachers on the ban of corporal punishment in pre-primary institutions. The objectives of the study were to investigate teachers' attitudes towards corporal punishment ban in pre-schools and to establish whether the level of education of teachers had an influence on the use of corporal punishment. A descriptive survey design was used. Stratified sampling was used to select the pre-schools; simple random sampling was applied to select all the teachers in the pre-schools. Data was collected through questionnaires and analyzed using both quantitative and qualitative approaches. Major findings indicated that: $71 \%$ agreed that reasonable corporal punishment is beneficial to the pre-school learners; $80 \%$ of the pre-school teachers used corporal punishment to maintain order in the classroom; Teachers perceived negatively the outlawing of corporal punishment; the level of teachers' education had no influence on the use of corporal punishment. The instances when corporal punishment was used by teachers were non-academic. The results form a basis of re-thinking the initial teachers training curriculum and subsequent in-service training in regard to classroom disruptions and how best they could be handled. As changes occur in educational setting, courses for training of teachers in the initial course, induction course or later in-service courses must reflect such changes and support and develop relevant skills in the staff upon whom these changes will impinge. The teacher trainee ought to be exposed to other methods of behaviour modification and these methods should have their own content and well researched.
\end{abstract}

Keywords: pre-schools; perception; attitude; corporal punishment

\section{Introduction}

An impassionate debate has been raging over the media regarding what is permissible and effective in raising children, and although many societies differ in many aspects of their cultures such as religion, mode of worship, rites of passage and language among others, they generally agree on the education or socialization that the young members of the society should receive; that is the transmission of each society's culture.

Parents and other caretakers such as teachers are the most important influences during the early years which are the most crucial in a child's life. This is because the experiences build on (Cashdan and Overall, 1998). Parents start the process of socialization where a child experiences receiving, sharing and giving: The three important aspects of social behaviours in school (Durajaiye, 1976). During this early period which is the most formative and most impressionable of the child's life, schools which serve as a socialization function as the first organization the children becomes a member (Datta, 1984), lay the foundations of learning in all its various forms. What children learn in this process is not only common practice and institutions of culture such as language, dress code; what is considered edible and expected roles; but also the society's world view. This is the complex of motivations, perceptions and beliefs that are internalized and they strongly affect interaction with other people and things in nature. A world view is rarely verbalised, but is inferred by actions. It is a set of feelings and basic attitudes about the world rather than clearly formulated opinions about it. The world view is concerned with core values; these are the fundamental values that provide the basis of social behaviour. Culture is a society's common fund of beliefs and behaviours and its concepts of how people should conduct themselves, culture defines the generally accepted principles of child rearing and care of children. These are standards by which members of a culture define what is 
desirable or undesirable; good or bad; beautiful or ugly (Macionis, 1991). They are broad principles, evaluations, judgements and standpoints that are learned through socialization both at home and in schools. The role of parents, therefore, in nurturing young children before and during their time at school is a vital part of the socialization process.

The mutual benefit of a two way home-school experience for moral development of the young cannot be overemphasized (Cashdan and Overall, 1998). How parents, teachers and caregivers attempt to shape their children's moral behaviour and how they would like children to respond is a highly culturally determined process. Different cultures have different rules about what is acceptable parenting practice, and views on children rearing, across cultures are divergent. To say the least, culture is the content of any education system and as (Lenzen, 1994) puts it: Education as a science cannot be separated from the education traditions that existed before. These traditions lay a lot of emphasis on the principle of what is right and wrong behaviour. Morally upright children are seen to be disciplined. Discipline is a set of behaviours, responses and attitudes that are endorsed by those in higher hierarchical position, that is, those mandated by the society for example parents and teachers to shape guide and or mould those under their care and responsibility, these are the young learners. These are the societal expectations that parents and teachers are supposed to fulfil through correct child rearing practices and therefore these traditional child rearing practices become more of a matter of traditions, habitual patterns and unspoken assumptions than of the conscious choices to be made by parents and teachers (Larkin, 1988). In most cultures appropriate child behaviour is promoted through social controls. This is mainly reinforcement. Reinforcement can be positive or negative. Positive: To reward conformity and, negative: To punish deviance.

The goal of discipline in any society however is not to control children and make them obey, but is to give them skills for making decisions, gradually gaining self control and being responsible for their own behaviour. The best time to develop good behaviour is when one is still young and it is easy to adapt habits that foster discipline (Sumbuye, 2004). Adaption of these habits does not always happen, deviant behaviour often arises and there is need for behaviour modification. Behaviour modifications are techniques of altering an individual's behaviour and reaction to stimuli through positive and negative reinforcement. All the same, deviant behaviour by young learners should be taken positively by parents and teachers because it would not only be communicating a need for help in directing the learners behaviour, but it could also serve as an opportunity to teach new and appropriate behaviour.

To main discipline, rules are set to act as guides of behaviour by the learners. Flouting of the rules of behaviour, endorsed by parents and teachers deserves punishment. Punishment is the administering of an aversive stimuli contingent upon disapproved behaviour. In schools, there are a wide range of punishments, but corporal punishment will be the focus here. It includes a wide range of physical actions meant to inflict pain and discomfort.

Thinking about the effectiveness and appropriateness of corporal punishment is as old as education itself. The wide range of vocabulary given to the act shows how well it is deeply embedded in our cultural systems. The English language for example has a remarkable vocabulary to cover hitting children such as smacking, slapping, paddling, clouting, canning (six of the best), thrashing, belting, strapping, walloping, tanning and whacking (Newell, 1989).

The use of these actions not only varies in intensity but also in regard to how often they are applied (Kerby, 2008). Corporal punishment is used for such purposes as stopping a learner's unwanted behaviour; preventing recurrence of unwanted behaviour or if the learner fails to do something she or he is supposed to do. These acts of deviance are seen as disturbances that abstract the process of the learner's socialization (Datta, 1984). Corporal punishment in pre-schools comes in various forms such as canning, running round the field, ridicule, kneeling, extra class work and detention. Though corporal punishment is intentionally causing pain to a child for the purpose of moulding (Goldman, 2004), broadly it can refer to a wide spectrum of punishment ranging from forced labour to mutilating torture and can also take the form of painful body postures (Benatar, 2002).

The school is a miniature society where the social and physical environment of the society is hostile, the school environment is not spared. The schools values and assessment adequacy of the learners' behaviour should be seen in the light of requirements of the society as a whole because the role of the punishment in the school setting is precisely the same as its role in the wider society; it is an expression of social morality. If there is corporal punishment in school, then it reflects the levels and pattern of the same in society. Though corporal punishment implies the infliction of pain, it is morally justified. It is an act of communication supposed to connect one with the correct values flouted (Norzick, 2007). The appropriateness of disciplinary methods is also determined in part by a child's perception of the legitimacy of the method. In a culture that widely endorses spanking the child may not perceive spanking as unusual. If spanking is culturally condoned and considered a manifestation of care and parental involvement, it may not have such negative effects as when it is judged by a child as a manifestation of parental 
aggression. In fact it is suggested that in African American families, spanking might be correlated with more parental warmth and reasoning with children (Gernoe \& Manner, 1997). Children statements indicate conception of punishment as a means to prevent further misbehaviour (Renate and Sabine, 1995). Children perceive punishment quite rightly as a justifiable consequence of the violation of a moral code of behaviour, this however varies with age. For examples in a research done in Uganda and Nigeria respectively, $83 \%-85 \%$ of ages $5-7$ thought it alright to beat people or make them suffer for the wrong doing (Durajaye, 1976). According to Piaget's study retribution was stressed by young learners who tend to see punishment as just, necessary and effective to the extent that the learner is made more obedient by means of sensible pain (Renate and Sabine 1995). According to (Riak, 1996), spanking is not a generative cause of aggression or pathology in children when appropriately used. He is of the view that corporal punishment works well with young learners. A small amount of discomfort goes a long way towards softening a child's rebellious spirit (Kerby, 2008).

Parental beliefs about children also guide their actions and help them direct their behaviour rationally. It is therefore important to listen to parents, teachers and caregivers' account of what they do and why because this would explain and make their actions understandable. Though corporal punishment is illegal in most countries, it is still an acceptable practice in most of these countries. Parents in English speaking West Indies believe it is necessary to use physical punishment to raise children (Gopaul Mc-Nicol, 1999). They see mild forms of spanking as an act of love, the necessary ingredient to teach children limits: For instance to punish disobedience, talking back, questioning or challenging directives, laziness and aggression towards others. In a research conducted in Chile and Costa Rica about $30 \%$ of parents said children should be hit sometimes or always when they misbehave (Lopez et al, 2002).

Corporal punishment has been used by adults in many African child rearing patterns. In moral training of African children, social sanctions always involve punishment and violation of any of the rules of the society usually would lead to punishment (Durajaye, 1976) which is given in the believe that it would prevent the recurrence of the behaviour for which it was given. Prohibiting corporal punishment would therefore constitute a serious sense of interference with the liberty and interest of parents who judge the possibilities of corporal punishment to benefit their children. For many parents, it is very important that no transgressions go unpunished because otherwise the child would become spoiled (Maldonado Duran et. al., 2003). From this social background therefore, punishment in schools can be understood to serve as a socialization function. It not only facilitates the move from jurisdiction of the family to the jurisdiction of the state, teaching the child that punishment is not always inflicted by family members, but also punishes the guilty (Benatar, 2002).

The move to ban corporal punishment started during the $18^{\text {th }}$ century when the ideas of freedom, democracy and self determination were proclaimed by progressive thinkers. The basic tenet was the replacement of authority by freedom, that is, to teach a child without the use of force by appealing to his curiosity and spontaneous need. This marked the beginning of progressive education. The move to ban corporal punishment can only be attributed to political pressure and timely ideas which influence the policy makers and the policies made (Westoby, 1988). The new policies banning corporal punishment ask schools to sacrifice long standing traditions for untested innovations. Although it would be foolish to argue that policy makers should not encourage change, it would be equally absurd to expect that policy makers, governments and or non governmental organizations can dictate values, patterns and practices in any given society. The most policy makers can do is the formality work such as legalizing the ban, but people in each community will dictate through words and deeds what to accept and implement (Westoby, 1988).

The discrepancy that exists regarding corporal punishment, between the law and the reality is an indicator that the interventions by policy makers are driven by consideration outside the specific demands of the client group (Gray et al, 1994). Though child abuse and neglect have documented in most cultures since the dawn of civilization (Haase and Kempe, 1990), any policies concerning the society should be culturally informed (Tom and Silva, 1992). The universal call to ban corporal punishment did not put this factor into consideration. The focus was child abuse neglecting all the known merits. This misunderstanding occurs because while parents world over are expected to provide sustenance, supervision and discipline, there are variations in the way they meet these obligations, this is because caretaking practices which are acceptable and appropriate in one society may be viewed by others as being wrong and abusive. This difference in values whether social, cultural, religious or moral result in variations in what is viewed as proper child rearing. Consequently the tug to war on whether to spank or not has persisted.

Lack of knowledge regarding culturally different child rearing practices also creates fertile ground for further misjudging the appropriateness of such practices as corporal punishment (Tom and Silva, 1992). The fact remains, there cannot be a rule book for raising children because this would be to ignore the fact that each child and its environment both physical and social are unique and therefore demand unique responses from its immediate society. 
Corporal punishment in Kenya was banned through (Kenya Gazette, 2001). Through the gazette notice the government scrapped sections of the law that permitted corporal punishment. Although the government outlawed by form of physical punishment on children in learning institutions, corporal punishment is still practiced in homes and many more institutions countrywide (Sunday Nation April $4^{\text {th }}$ 2010), this includes kneeling for hours, kicking, slapping, giving a lot of academic work and engaging in difficult games. Pressure from parents who want their children punished in the event of misbehaviours has further complicated the issue. The teachers have therefore continued using corporal punishment even after the legal ban. Therefore, this study was undertaken to establish the justification of the continued application of corporal punishment in pre-primary institutions. Specifically the perceptions of teachers on the use of corporal punishment in pre-primary institutions despite the ban.

\subsection{Objectives of the Study}

The objectives of the study were to investigate:

- Perceptions of teachers on corporal punishment in pre-primary schools;

- Other methods used by teachers to modify behaviour;

- Whether the level of education of teachers had influence on the use of corporal punishment;

- Instances when corporal punishment was used.

1.2 Limitations of the Study

- Though there are many external standards imposed on learners in Pre-school in the event of discipline, the research only focussed on corporal punishment.

- $\quad$ Limited to responses given by teachers knowing that corporal punishment was illegal.

\subsection{Assumptions of the Study}

The study was carried out on the assumption that all teachers were aware that corporal punishment was banned and corporal punishment was still used in schools to enhance discipline.

\section{Methodology}

\subsection{Research Design}

The study adopted a descriptive survey research design to study the perceptions of teachers on the ban of corporal punishment in pre-primary institutions. This design was selected because it is convenient in collecting substantial amount of views from respondents over a wide area (Koul, 1992). The survey research design generally entails collection of data about subjects as they are found in a social system providing quantitative and numeric descriptions of some part of the population (Oso and Onen, 2005). For the purpose of this study, the design provided a snap short of attitudes, conditions and relations as concerns corporal punishment and socialization process.

\subsection{Population and Sample}

The target population of this study comprised all teachers of the pre-primary schools in Uasin Gishu county. Stratified sampling and simple random sampling techniques were used to select samples that were drawn independently and randomly from the stratum of pre-primary schools. Stratified sampling technique refers to identifying subgroups in the population and their proportion and selecting from each sub group to form a sample. It is mainly used group a population into homogenous subsets that share similar characteristics. In this study, it was used to group pre-schools into private, public, religious and municipal run schools. It was preferred because it ensured equitable representation of the population in the sample.

Simple random sampling technique involves selecting the sample without bias from the target population. It was mainly used to select a random representative sample. All teachers from the sampled pre-schools were used in the study. It was preferred because it ensured that each member if the target population had an equal and independent chance of being included in the sample.

Sixty four pre-schools were samples and all the 128 teachers of the sampled pre-schools constituted the sample of the study.

\subsection{Data Collection Procedure}

The researchers wrote introductory letters to the concerned persons before commencement of the research fieldwork explaining the purpose of the research and then requested them to assist by proving the data through questionnaires. 
The researchers visited the pre-schools.

\subsection{Data Analysis}

The data was coded and entered into the statistical package for social sciences (SPSS) for analysis and interpretation. The data was analysed using descriptive statistics. Frequency counts and percentages were used to analyse the data. The quantitative analysis was supplemented by qualitative descriptions to provide a fuller picture of the results particularly in those areas that are not easily amenable to quantification. Data was presented by use of tables; frequencies and percentages were used to describe the degree of relationship between variables.

\section{Results}

\subsection{Teachers' Perceptions towards Corporal Punishment Ban in Schools}

The results are presented in table 1. The results indicate that some of the respondents expressed supportive or neutral opinions on statements supporting the ban of corporal punishment. Teachers who indicated indecision were more likely to use the method they have always used - corporal punishment.

Table 1. Teachers' Perceptions on Corporal Punishment

\begin{tabular}{|c|c|c|c|c|c|c|c|c|c|}
\hline & & Agree & & Undecided & & Disagree & & Total & \\
\hline & & Frequency & Percent & Frequency & Percent & Frequency & Percent & Frequency & Percent \\
\hline 1. & $\begin{array}{l}\text { Teachers should use corporal } \\
\text { punishment to modify deviant behaviour }\end{array}$ & 52 & 41.00 & 4 & 3.00 & 72 & 56.00 & 128 & 100 \\
\hline 2. & $\begin{array}{l}\text { Corporal punishment has outlived its } \\
\text { usefulness }\end{array}$ & 64 & 50.00 & 22 & 17.00 & 42 & 33.00 & 128 & 100 \\
\hline 3. & $\begin{array}{l}\text { Teachers should use corporal } \\
\text { punishment to modify deviant behaviour }\end{array}$ & 67 & 53.00 & 11 & 9.00 & 50 & 38.00 & 128 & 100 \\
\hline 4. & $\begin{array}{l}\text { Children prefer corporal punishment to } \\
\text { other forms of punishment }\end{array}$ & 21 & 16.00 & 18 & 14.00 & 89 & 70.00 & 128 & 100 \\
\hline 5. & $\begin{array}{l}\text { Reasonable corporal punishment is } \\
\text { beneficial to pre-school learners }\end{array}$ & 90 & 71.00 & 5 & 4.00 & 33 & 25.00 & 128 & 100 \\
\hline 6. & $\begin{array}{l}\text { Corporal punishment makes children } \\
\text { respect teachers }\end{array}$ & 51 & 40.00 & 10 & 8.00 & 67 & 52.00 & 128 & 100 \\
\hline 7. & $\begin{array}{l}\text { Corporal punishment should be used as a } \\
\text { last resort }\end{array}$ & 81 & 67.00 & 6 & 5.00 & 37 & 28.00 & 128 & 100 \\
\hline 8. & It hurts me to give corporal punishment & 84 & 65.00 & 6 & 5.00 & 38 & 30.00 & 128 & 100 \\
\hline 9. & $\begin{array}{l}\text { Corporal punishment makes learners } \\
\text { dislike school }\end{array}$ & 86 & 71.00 & 5 & 4.00 & 37 & 25.00 & 128 & 100 \\
\hline 10. & $\begin{array}{l}\text { Teachers should be allowed to use } \\
\text { corporal punishment with discretion }\end{array}$ & 57 & 44.00 & 17 & 13.00 & 54 & 43.00 & 128 & 100 \\
\hline 11. & $\begin{array}{l}\text { Corporal punishment degrades the } \\
\text { teacher }\end{array}$ & 40 & 31.00 & 18 & 14.00 & 70 & 55.00 & 128 & 100 \\
\hline 12. & $\begin{array}{l}\text { Corporal punishment ban restricted the } \\
\text { teacher }\end{array}$ & 70 & 56.00 & 20 & 15.00 & 38 & 29.00 & 128 & 100 \\
\hline 13. & $\begin{array}{l}\text { Corporal punishment ban should be } \\
\text { lifted }\end{array}$ & 67 & 53.00 & 19 & 15.00 & 42 & 32.00 & 128 & 100 \\
\hline 14. & $\begin{array}{l}\text { Corporal punishment does more harm } \\
\text { than good }\end{array}$ & 72 & 57.00 & 9 & 7.00 & 47 & 36.00 & 128 & 100 \\
\hline
\end{tabular}

Teachers were supposed to implement the ban and therefore it was expected of them to go by the rule of law. For example in the first statement $56 \%$ indicated that teachers should not use corporal punishment. $50 \%$ also indicated corporal punishment has outlived its usefulness while 53\% indicated all corporal punishment in pre-school should be abandoned. $65 \%$ also indicated it hurt them to give corporal punishment. But asked in statement five whether reasonable corporal punishment is beneficial to pre-school learners $71 \%$ are in agreement. $55 \%$ disagree that engaging in Corporal

Punishment degrades the teacher. 56\% indicated the ban had restricted the teacher and 53\% indicated the ban should be lifted. These results implied that teachers still depended on corporal punishment to solve classroom disruptions and misbehaviour. The teachers sees the ban as a formal directive that is unrealistic rather than a practical strategy to handle indiscipline (Chiang, 2009). The use of corporal punishment is a reflection of the attitudes and behaviour of the whole society and cannot be studied or understood without reference to the society which the school and the teacher are part of. 
Since $50 \%$ of the teachers indicated corporal punishment had outlived its usefulness, researchers sort to find out other methods they used to modify behaviour or complement corporal punishment.

\subsection{Other Methods Used to Modify Behaviour}

Table 2. Other Methods Used to Modify Behaviour

\begin{tabular}{lll}
\hline & Frequency & Percent \\
\hline Corporal Punishment & 102 & 80.00 \\
Others & 26 & 20.00 \\
Total & $\mathbf{1 2 8}$ & $\mathbf{1 0 0 . 0 0}$
\end{tabular}

Results from the above table indicate that teachers still depend on corporal punishment to modify behaviour. This implies that teachers felt corporal punishment was working for them to maintain order in classroom.

Further feeling of teachers were sought by asking them whether corporal punishment was child abuse. Teachers, as indicated in table 3 never viewed corporal punishment as child abuse. $38 \%$ said it is not child abuse, while $23 \%$ said sometimes it can be child abuse. $1 \%$ of teachers indicated that it is rarely child abuse. These results pointed to the fact that if teachers who were supposed to implement the ban did not see corporal punishment as child abuse, then corporal punishment was very much in use in the Kenyan pre-schools. Corporal Punishment in USA schools (Stephy, 2009) is still condoned by educators because they face the difficult task of maintaining order in the classroom and because the schools lack resources and training for alternative methods of discipline.

Table 3. Is Corporal Punishment Child Abuse?

\begin{tabular}{lll}
\hline & Teachers & \\
\hline Yes & Frequency & Percent \\
No & 41 & 32.00 \\
I don't know & 49 & 38.00 \\
Most of the time & 4 & 3.00 \\
Sometimes & 4 & 3.00 \\
Rarely & 29 & 23.00 \\
Total & 1 & 1.00 \\
\hline
\end{tabular}

\subsection{Does the Level of Education of Teachers have an Influence on the Use of Corporal Punishment}

The third objective of this study was to investigate if the level of education of teachers had an influence on the use of corporal punishment. To achieve this objective, respondents were asked to indicate the highest level of education reached. Four categories were identified that is, primary, secondary, mid-level colleges and university.

Table 4 indicates that $56 \%$ of all teachers disagreed teachers should use corporal punishment. As the table 4 indicates $19 \%$ of them had basic education and $81 \%$ of them has tertiary education. Teachers with tertiary education indicated the highest level of disagreement and indecision. This agrees with (Shumba, 2001) as quoted in (Busienei, 2008) who asserts that untrained teachers were expected to be slightly less familiar with the laws and regulations governing their position and the use of corporal punishment in schools, but differed with (Muthiani, 1996) whose work showed no significant difference on teachers' level of education and their perception towards outlawing of corporal punishment.

Table 4. Teachers should use Corporal Punishment to Modify Deviant Behaviour

\begin{tabular}{|c|c|c|c|c|c|c|c|c|c|c|}
\hline & \multicolumn{2}{|c|}{ Primary } & \multicolumn{2}{|c|}{ Secondary } & \multicolumn{2}{|c|}{ College } & \multicolumn{2}{|c|}{ University } & \multicolumn{2}{|c|}{ Total } \\
\hline & f & $\%$ & f & $\%$ & f & $\%$ & f & $\%$ & f & $\%$ \\
\hline Agree & 2 & 4.00 & 12 & 23.00 & 37 & 71.00 & 1 & 2.00 & 52 & 100.00 \\
\hline Undecided & 0 & 0.00 & 1 & 25.00 & 3 & 75.00 & 0 & 0.00 & 4 & 100.00 \\
\hline Disagree & 1 & 1.00 & 13 & 18.00 & 58 & 81.00 & 0 & 0.00 & 72 & 100.00 \\
\hline
\end{tabular}

Table 5. Corporal Punishment has Outlived Its Usefulness

\begin{tabular}{|c|c|c|c|c|c|c|c|c|c|c|}
\hline & \multicolumn{2}{|c|}{ Primary } & \multicolumn{2}{|c|}{ Secondary } & \multicolumn{2}{|c|}{ College } & \multicolumn{2}{|c|}{ University } & \multicolumn{2}{|c|}{ Total } \\
\hline & f & $\%$ & f & $\%$ & f & $\%$ & $\mathbf{f}$ & $\%$ & f & $\%$ \\
\hline Agree & 3 & 5.00 & 10 & 16.00 & 51 & 79.00 & 0 & 0.00 & 64 & 100.00 \\
\hline Undecided & 0 & 0.00 & 4 & 18.00 & 18 & 82.00 & 0 & 0.00 & 22 & 100.00 \\
\hline Disagree & 0 & 0.00 & 12 & 29.00 & 29 & 69.00 & 1 & 2.00 & 42 & 100.00 \\
\hline
\end{tabular}


Table 5 indicates that $21 \%$ of those with basic education and $79 \%$ of those with tertiary education agreed that corporal punishment had outlived its usefulness. While $82 \%$ of those with tertiary education indicated indecision, $71 \%$ of the same disagreed corporal punishment has outlived its usefulness. This agrees with (Cooper and Moore, 1984) who found out that those teachers with lower levels of education and experience were more likely to report examples of problem behaviour and therefore still use corporal punishment to modify behaviour. The high levels of indecision among those with tertiary education could also be an indicator the ban was imposed.

Table 6. All Corporal Punishment in Pre-School Should be Abandoned

\begin{tabular}{|c|c|c|c|c|c|c|c|c|c|c|}
\hline & \multicolumn{2}{|c|}{ Primary } & \multicolumn{2}{|c|}{ Secondary } & \multicolumn{2}{|c|}{ College } & \multicolumn{2}{|c|}{ University } & \multicolumn{2}{|c|}{ Total } \\
\hline & f & $\%$ & f & $\%$ & f & $\%$ & $f$ & $\%$ & f & $\%$ \\
\hline Agree & 2 & 3.00 & 13 & 19.00 & 52 & 78.00 & 0 & 0.00 & 67 & 100.00 \\
\hline Undecided & 1 & 9.00 & 1 & 9.00 & 9 & 82.00 & 0 & 0.00 & 11 & 100.00 \\
\hline Disagree & 0 & 0.00 & 12 & 24.00 & 37 & 74.00 & 1 & 2.00 & 50 & 100.00 \\
\hline
\end{tabular}

Table 6 shows that $53 \%$ of teachers agree corporal punishment should be abandoned. $22 \%$ of them had basic education and $78 \%$ had tertiary education. Those with tertiary education were more convinced that corporal punishment should be abandoned. This agreed with (Shumba, 2001) as cited in (Busienei, 2008) who argues that a trained teacher is expected to be familiar with the regulations and laws that protect learners against physical abuse.

Table 7. Children prefer Corporal Punishment to other forms of Punishment

\begin{tabular}{|c|c|c|c|c|c|c|c|c|c|c|}
\hline & \multicolumn{2}{|c|}{ Primary } & \multicolumn{2}{|c|}{ Secondary } & \multicolumn{2}{|c|}{ College } & \multicolumn{2}{|c|}{ University } & \multicolumn{2}{|c|}{ Total } \\
\hline & f & $\%$ & f & $\%$ & f & $\%$ & f & $\%$ & f & $\%$ \\
\hline Agree & 0 & 0.00 & 3 & 14.00 & 18 & 86.00 & 0 & 0.00 & 21 & 100.00 \\
\hline Undecided & 1 & 2.00 & 4 & 8.00 & 46 & 90.00 & 0 & 0.00 & 51 & 100.00 \\
\hline Disagree & 2 & 3.00 & 19 & 34.00 & 34 & 61.00 & 1 & 2.00 & 56 & 100.00 \\
\hline
\end{tabular}

Table 7 shows that $70 \%$ of teachers disagreed that children prefer corporal punishment to other forms of punishment with those with basic education indicating $37 \%$ and $63 \%$ for those with tertiary education. This is in agreement with (Melgosa, 2002, Kipkemboi, 2009) who says students have a negative attitude towards corporal punishment and argues that one thing to be remembered regarding behaviour modification strategies is that the method used in early childhood cannot be used in adolescence. In early childhood authority is unquestionable. Liking or not liking does not arise; a pre-scholar needs to learn between right and wrong quickly.

Table 8. Reasonable Corporal Punishment is Beneficial to Pre-School Learners

\begin{tabular}{|c|c|c|c|c|c|c|c|c|c|c|}
\hline & \multicolumn{2}{|c|}{ Primary } & \multicolumn{2}{|c|}{ Secondary } & \multicolumn{2}{|c|}{ College } & \multicolumn{2}{|c|}{ University } & \multicolumn{2}{|c|}{ Total } \\
\hline & f & $\%$ & $\mathbf{f}$ & $\%$ & f & $\%$ & f & $\%$ & f & $\%$ \\
\hline Agree & 2 & 2.00 & 17 & 19.00 & 70 & 78.00 & 1 & 1.00 & 90 & 100.00 \\
\hline Undecided & 0 & 0.00 & 2 & 40.00 & 3 & 60.00 & 0 & 0.00 & 5 & 100.00 \\
\hline Disagree & 1 & 3.00 & 7 & 21.00 & 25 & 76.00 & 0 & 0.00 & 33 & 100.00 \\
\hline
\end{tabular}

Table 8 shows that $71 \%$ of teachers agreed that reasonable corporal punishment is beneficial to pre-school learners. $79 \%$ of those with tertiary education and $21 \%$ of those with basic education are in agreement. This resonates well with (Mbiti, 1974) who argues that the use of punishment is a method to curb indiscipline among others like, school rules and regulations; guidance and counselling; religious education and many more. Punishment is to both deter and retribute the offenders (Okumbe, 1999). Corporal punishment as a corrective discipline is aimed at discouraging further infringement of the rule. While most teachers adhere to the ban in respect of its harsher forms of corporal punishment many continue to views its milder forms as a practical tool for pupil control and motivation (Chiang, 2009).

Table 9. Corporal Punishment Makes Learners Respect Teachers

\begin{tabular}{lllllllllll}
\hline & \multicolumn{2}{l}{ Primary } & \multicolumn{2}{c}{ Secondary } & \multicolumn{2}{c}{ College } & \multicolumn{2}{c}{ University } & \multicolumn{2}{c}{ Total } \\
\cline { 2 - 11 } & f & $\mathbf{\%}$ & f & $\mathbf{\%}$ & f & $\mathbf{\%}$ & f & $\mathbf{\%}$ & f & \% \\
\hline Agree & 2 & 4.00 & 10 & 20.00 & 38 & 76.00 & 1 & 2.00 & 51 & 100.00 \\
Undecided & 0 & 0.00 & 4 & 40.00 & 6 & 60.00 & 0 & 0.00 & 10 & 100.00 \\
Disagree & 1 & 1.00 & 12 & 18.00 & 54 & 81.00 & 0 & 0.00 & 67 & 100.00 \\
\hline
\end{tabular}


Table 9 shows that $52 \%$ of teachers disagreed with the statement, $81 \%$ of them had tertiary education. This agrees with (Tuba, 2000) who say corporal punishment establishes a barrier between the teacher and the learner and also lowers other learners' respect for the teacher, but differs with (Subulica, 2009) who argues that corporal punishment should be combined with other methods to improve the behaviour and make learners respect the teacher.

Table 10. Corporal Punishment Should be used as a Last Resort

\begin{tabular}{lllllllllll}
\hline & Primary & \multicolumn{2}{c}{ Secondary } & \multicolumn{2}{c}{ College } & \multicolumn{2}{c}{ University } & \multicolumn{2}{c}{ Total } \\
& f & $\mathbf{\%}$ & f & $\mathbf{\%}$ & f & $\mathbf{\%}$ & f & $\mathbf{\%}$ & f & $\mathbf{\%}$ \\
\hline Agree & 3 & 3.00 & 15 & 18.00 & 66 & 78.00 & 1 & 1.00 & 85 & 100.00 \\
Undecided & 0 & 0.00 & 0 & 0.00 & 6 & 100.00 & 0 & 0.00 & 6 & 100.00 \\
Disagree & 0 & 0.00 & 11 & 30.00 & 26 & 70.00 & 0 & 0.00 & 37 & 100.00 \\
\hline
\end{tabular}

Table 10 indicates that $67 \%$ of teachers agreed that corporal punishment should be used as a last resort. $79 \%$ of them had tertiary education. This is an indicator that teachers at this level because of the training are ready to embrace other methods of behaviour modification. This agrees with (Loretta, 2004) in the dissertation "Teachers attitudes towards the abolition of corporal punishment in South Africa, which reports that teachers have found alternatives that work, however they still feel that the training that is provided is not able to meet their needs in the classroom situation. Corporal punishment should remain as an option.

Table 11. Teachers should be Allowed to Use Corporal Punishment with Discretion

\begin{tabular}{|c|c|c|c|c|c|c|c|c|c|c|}
\hline & \multicolumn{2}{|c|}{ Primary } & \multicolumn{2}{|c|}{ Secondary } & \multicolumn{2}{|c|}{ College } & \multicolumn{2}{|c|}{ University } & \multicolumn{2}{|c|}{ Total } \\
\hline & f & $\%$ & f & $\%$ & f & $\%$ & f & $\%$ & f & $\%$ \\
\hline Agree & 1 & 2.00 & 11 & 19.00 & 44 & 77.00 & 1 & 2.00 & 57 & 100.00 \\
\hline Undecided & 0 & 0.00 & 4 & 24.00 & 13 & 76.00 & 0 & 0.00 & 17 & 100.00 \\
\hline Disagree & 2 & 4.00 & 11 & 20.00 & 41 & 76.00 & 0 & 0.00 & 54 & 100.00 \\
\hline
\end{tabular}

Table 11 shows that $44 \%$ of teachers agreed that teachers should be allowed to use corporal punishment with discretion. $79 \%$ of them had tertiary education. From the above table 11, there was a higher percentage of indecision on whether teachers should be allowed to use corporal punishment with discretion. This indicated a conflicting stand especially in teachers with tertiary education because they knew the rule and they are also expected to implement it. This agreed with (Robb, 2001) who argues that in order for teachers to engage in new practices in schools they must first address their own thinking.

Table 12. Engaging in Corporal Punishment Degrades the Teacher

\begin{tabular}{|c|c|c|c|c|c|c|c|c|c|c|}
\hline & \multicolumn{2}{|c|}{ Primary } & \multicolumn{2}{|c|}{ Secondary } & \multicolumn{2}{|c|}{ College } & \multicolumn{2}{|c|}{ University } & \multicolumn{2}{|c|}{ Total } \\
\hline & f & $\%$ & f & $\%$ & f & $\%$ & f & $\%$ & f & $\%$ \\
\hline Agree & 1 & 3.00 & 9 & 22.00 & 30 & 75.00 & 0 & 0.00 & 40 & 100.00 \\
\hline Undecided & 0 & 0.00 & 2 & 11.00 & 15 & 83.00 & 1 & 6.00 & 18 & 100.00 \\
\hline Disagree & 2 & 2.00 & 15 & 21.00 & 53 & 77.00 & 0 & 0.00 & 70 & 100.00 \\
\hline
\end{tabular}

Table 12 indicates that $55 \%$ of teachers disagreed with the statement corporal punishment degrades the teacher. From the above table $11,75 \%$ of the respondents had tertiary education. According to (Tuba, 2000) teaching is difficult for the teacher to teacher and control the learners' behaviour at the same time and therefore discipline needs to occur post haste after an infraction of any sort happens. Corporal punishment provides this.

Table 13. Corporal Punishment Ban has Restricted the Teacher

\begin{tabular}{lllllllllll}
\hline & Primary & \multicolumn{3}{c}{ Secondary } & \multicolumn{2}{c}{ College } & \multicolumn{2}{c}{ University } & \multicolumn{2}{c}{ Total } \\
\cline { 2 - 11 } & f & $\mathbf{\%}$ & f & $\mathbf{\%}$ & f & $\mathbf{\%}$ & f & \% & f & \% \\
\hline Agree & 1 & 2.00 & 14 & 20.00 & 54 & 77.00 & 1 & 1.00 & 70 & 100.00 \\
Undecided & 1 & 5.00 & 2 & 10.00 & 17 & 85.00 & 0 & 0.00 & 20 & 100.00 \\
Disagree & 1 & 3.00 & 10 & 26.00 & 27 & 71.00 & 0 & 0.00 & 38 & 100.00 \\
\hline
\end{tabular}

Table 13 shows that $56 \%$ of teachers agreed that the ban has restricted the teacher in matters of school discipline. $78 \%$ of those teachers had tertiary education. Those with tertiary education seem to agree more with the statement. This supports (Nsubuga, 2000) who asserts that punishment is sometimes necessary to maintain order and provide a safe environment for all learners. Corporal punishment is used to endorse these values. 
Table 14. Corporal Punishment Ban should be Lifted

\begin{tabular}{lllllllllll}
\hline & Primary & \multicolumn{4}{c}{ Secondary } & \multicolumn{2}{c}{ College } & \multicolumn{2}{c}{ University } & Total \\
\hline & f & $\mathbf{\%}$ & $\mathbf{f}$ & $\mathbf{\%}$ & $\mathbf{f}$ & $\mathbf{\%}$ & $\mathbf{f}$ & $\mathbf{\%}$ & $\mathbf{f}$ & $\mathbf{\%}$ \\
\hline Agree & 2 & 3.00 & 15 & 22.00 & 49 & 73.00 & 1 & 2.00 & 67 & 100.00 \\
Undecided & 1 & 5.00 & 3 & 16.00 & 15 & 79.00 & 0 & 0.00 & 19 & 100.00 \\
Disagree & 0 & 0.00 & 8 & 19.00 & 34 & 81.00 & 0 & 0.00 & 42 & 100.00 \\
\hline
\end{tabular}

Table 14 indicates that $53 \%$ of the teachers were in agreement that the ban should be lifted. $75 \%$ of teachers with tertiary education were in agreement. According to (Hunt, 2007) teachers are unhappy with the ban because it is responsible for growing indiscipline. Corporal punishment in South African schools (Rademeyer, 2011), teachers claimed the ban was forced on them too quickly while they were not trained in other methods. This differed with (Kerby, 2007) a clinical psychologist who argues that corporal punishment has many side effects and it cannot be defined when corporal punishment becomes abusive.

\subsection{Instances when Corporal Punishment is Adminstered}

The fourth objective of this study was to find out instances when corporal punishment was used by teachers. To achieve this objective the respondents were asked to react to given statements. Data on this was collected and analyzed under the question: "What are the instances that corporal punishment is administered?" The results are presented in table 15 .

Table 15. Instances when Corporal Punishment is Administered by Teachers

\begin{tabular}{llllll}
\hline & & Teacher & & \\
\cline { 3 - 5 } & & Yes & Percent & No & Percent \\
\hline 1. & When a child fails class work & 22 & 17.00 & 106 & 83.00 \\
2. & When a child steals something & 89 & 70.00 & 39 & 30.00 \\
3. & When a child verbally abuses others & 74 & 58.00 & 54 & 42.00 \\
4. & When a child is stubborn & 49 & 38.00 & 79 & 62.00 \\
5. & Does not finish homework & 31 & 24.00 & 97 & 76.00 \\
6. & Child's work is untidy & 19 & 15.00 & 109 & 85.00 \\
7. & When a child uses taboo language & 98 & 77.00 & 30 & 23.00 \\
\hline
\end{tabular}

As indicated by the above table, teachers used corporal punishment not necessarily for class work, but for non-academic incidents e.g. when a child steals something. $70 \%$ of teachers responded they would use corporal punishment, $83 \%$ of teachers would not punish for class work failure. As a socializing agent a teacher is expected to socialize children into responsible members of the society by instilling the appropriate values, skills and attitudes. It also differs with (Finney, 2001) who suggests teachers slapped children who got their lessons incorrect.

\section{Conclusions and Policy Implications}

The results showed that majority of teachers indicated a positive inclination to items that agreed with corporal punishment. $71 \%$ of teachers indicated reasonable corporal punishment is beneficial to pre-school learners. $55 \%$ of teachers also disagreed that corporal punishment degrades the teachers. One of the explanations why the teachers still use corporal punishment even after the ban is the heavy duty placed on them by parents especially on moral behaviour modification. Teachers in pre-schools play three very different but important social roles. A social role is the expected behaviour associated with a social position. The roles are: Curricular transaction-this has to do with pre-school syllabus. Socialization-this has to do with instilling of values, attitudes and skills. Here the teacher is a disciplinarian, judge, role model and a parent. Associated welfare is another role where the teacher has to toilet train; feed the child and so on. To achieve these roles, the teachers had to have a workable and inexpensive model of behaviour modification. Teachers felt corporal punishment was more effective than other methods of behaviour modification because it did not only punish the misbehaviour, but also acted as a deterrent to others. The teachers felt the law should be amended to allow for limited use of corporal punishment in learning institutions.

Teachers indicated that they administered corporal punishment in virtually all wrong doings. What was very important here was the responses to matters not necessarily academic. One particular item on whether the teachers would punish if the learners stole something, $79 \%$ of teachers responded in the affirmative. This indicates that teachers in school are more concerned not with academic matters per se, but with what is seen to be acceptable in the society. This is hidden curriculum that consists of those things pupils learn through the experience of attending school rather than the stated educational objectives of such institutions. 
Most teachers perceived positively the use of corporal punishment. This could be because they were not equipped with other skills. The results form a basis for rethinking the initial teachers training curriculum and subsequent in-service training in regard to classroom disruptions and how best they could be handled. It is time the government through the ministry of education rethinks about teacher training programmes. Teacher education ought to incorporate the social truths; be flexible and in tendem with current realities. As changes occur in educational setting, courses for training of teachers in the initial courses, induction courses or later in-service courses must reflect such changes and support and develop relevant skills in the staff upon whom these changes will impinge. The teacher trainee ought to be exposed to other methods of behaviour modification and these methods should have their own content and well researched.

\section{References}

Benatar, D. (2002). Corporal Punishment. Retrieved from www.corpun.com/Benatar.ht

Busienei, A. (2008). Teachers Attitudes towards outlawing of Corporal Punishment in Schools. A case of Public Secondary School Teachers in Eldoret Municipality. M.Phil Thesis. Moi University, Eldoret.

Cashdab, A., \& Overall, L. (1998). Teaching in Primary Schools (Ed). London. Continuum.

Chiang, C. (2009). Taiwan Ban on Corporal Punishment. Retrieved from www.gradworks.umi.com.33/80/33808887.html

Cooper \& Moore. (1984). Preservice Teachers 'Perceptions of Children's Problem Behaviour. Retrieved from www.jsor.org/pss/27540334

Datta, A. (1984). Education. London. The MacMillan Press Ltd.

Durajaye, M. (1976). A New Introduction to Education Psychology. Nairoib: Evans Brothers Kenya Ltd.

Elizabeth, G. (2008). Report on Physical Punishment in the United States: What is the Most Effective Discipline for Children? Retrieved from www.achildsacademy.com/2010/04/27

Finney, D. (2001). Corporal Punishment in Schools. Retrieved from www.greatdream.com/corporal

Gernoe \& Manner. (1997). Discipline in Early Childhood. Retrieved from www.kaimh.org

Goldman, R. (2004). Corporal Punishment of Children: Think Globally Act Locally. Retrieved from www.nospank.net/n-mzzr.html

Gray, P., Miller, A., \& Noakes, J. (1194). Challenging Behaviour in Schools: Teacher Support Practical Technique and Policy Development. London. Routledge.

Haase, R., \& Kempe, S. (1990). The School and Protective Services. Education and Urban Society. http://dx.doi.org/10.1177/0013124590022003003

Kenyatta, J. (1938). Facing Mt. Kenya. Nairobi: East African Educational Publishers ltd.

Kerby, A. (2007). Banning Corporal Punishment: What the Arguments tell us about our Character Regarding the Treatment of Children. Retrieved from www.cicparenting.org/newsletters/bancorpEssay.html

Kipkemboi, W. (2009). "Secondary School Teachers and Students Perceptions of the Challenges to Moral Education in Uasin Gishu", M.Phil Thesis, Moi University, Eldoret.

Koul, L. (1992). Methodology of Educational Research (2 ${ }^{\text {nd }}$ ed). New Delhi (1997): Vilcas Publishing House Development Ltd.

Larkin, J. (1998). Children Everywhere. Retrieved from www.osv.org/education/children/everywhere/learning

Lenzen, D. (1994). Education: Not art, not books, but life itself is the true basis of teaching and education. Retrieved from www.edu/earsoc.org/chapters/20education/introduction.html

Levin, W. (1984). Towards the learning Society. London: Cassell Viliers House.

Lopez, M. et al. (2002). Culture issues in Corporal Punishment of Children. Retrieved from www.kaimh.org

Loretta, C. (2004). Teachers Attitudes towards the Abolition of Corporal Punishment in South Africa. Retrieved from www.uonbi.ac.ke.facilites

Macionis, J. (1991). Sociology ( $3^{\text {rd }}$ Ed.) United States of America Prentice Hall. 
Maldonado, D. et al. (2003). Discipline in Early Childhood. Retrieved from www.kaimh.org

Mbiti, D. (1974). Foundations of School Administration. Nairobi: Oxford University Press.

Melgosa. (2010). Improving Communication Between Parents and their Adolescents Children. JHER, 13, 85-92.

Muthiani, S. (1996). Teachers' Attitudes towards Corporal Punishment: A study of Primary and Secondary School in Yatta Division of Machakos County, Kenya.

Newell, P. (1989). Children are People Too: The Case Against Physical Punishment: Bedford Square Press.

Nozick, R. (2007). Punishment: Supposed Mixed Justification of it. Retrieved from www.icl.ac.uk-uctytho/punishment mixed Theories html

Nsubuga, E. (2000). The Teacher as a Professional. Kampala: M. K. Publishers.

Oso, Y., \& Onen, D. A. (2005). General Guide to Writing Research Proposal Report. Kisumu: Lake Publishers.

Okumbe, J. (1999). Educational Management: Theory and Practice. Nairobi: Nairobi University Press, 1999.

Renate, V., \& Sabine, W. (1995). Punishment is unavoidable-or is it? What Children think about Dealing with Wrongdoers. Education Journal, 51(52), 87-108.

Riak, J. (1996). The Short and Long-term Consequences of Corporal Punishment. Retrieved from www.nospank.net/riak.htl

Robb, M. (2001). Ending Corporal Punishment. Retrieved from www.suite/01.com/article.cfm/socialemotionallearning/59118

Rosabeth, M. (1972). The Organization Child: Experience Management in Nursery Schools. Sociology of Education Journal, 45, 186-210. http://dx.doi.org/10.2307/2112007

Stephy, M. (2009). Corporal Punishment in U.S.A Schools. Retrieved from www.time.com/time/nation

Sunday Nation: April $4^{\text {th }} 2010$.

Sumbuye, K. (2004). Brighten your Life. Nairobi: Pauline Publications Africa.

Tom, M., \& Silva, P. (1992). Culturally Diverse Childrearing Practice: Abusive or Just Different. Retrieved from (www.behaviouradvisor.com/c-chilabuse.html) (www.maxweber.hunter.cuny.edu/pub/eres/EDSPC715-MCINTYRE/C-childabuse.html)

Tuba, I. (2000). Classroom Management. Retrieved from www.inglish.com/classroommanagement.html Westoby, A. (1988). Culture and power in Educational organization. England: Open University Press. 